\title{
APARTMENT PRICE INDICES \\ ON THE EXAMPLE OF COOPERATIVE APARTMENTS SALE TRANSACTIONS
}

\author{
Iwona Foryś, Ph.D. \\ Department of Econometrics and Statistics \\ Faculty of Economics and Management \\ University of Szczecin \\ Mickiewicza 64, 71-101 Szczecin \\ e-mail:forys@wneiz.pl
}

Received 20 December 2010, Accepted 20 May 2011

\begin{abstract}
The article presents the review of methods used to construct apartment price indices in order to select a method of determining a price index for a chosen local apartment market in the West Pomeranian Province. The analysis covered 369 free-market sale transactions of cooperative apartments that had been concluded from 4 May 2000 to 18 August 2010 by a Housing Cooperative in the Zachód development in Stargard Szczeciński with the total number of 2,712 flats (constituting a stable and homogenous housing resource due to the time and technology of construction). To each transaction seven features have been attributed: a transaction date, a sale price, a property size, an address, a number of rooms, a floor and the number of floors in a building. The above considerations confirm the usefulness of classic indices of apartment price dynamics on a spatially limited market where it is possible to differentiate sets of apartments that are considered homogenous because of the similarity of their primary characteristics.
\end{abstract}

Keywords: apartment price index, local apartment price, housing attribute.

JEL classification: R31. 


\section{Introduction}

Turnover on the apartment market generates the demand for market value appraisal services, but more and more often a need emerges to determine apartment price tendencies and to define the practical value of this type of information in the price appraisal process. It is typical of the developed real estate markets to provide easy access to coherent and complete databases concerning transactions on these markets. The markets that have emerged recently often lack systems of gathering information about available property and its prices while those databases that are being developed are incomplete and do not represent the whole market. The Polish apartment market, despite being better described by the public statistical services ${ }^{1}$ than other segments of the local real estate market, does not offer a single and all-inclusive system of collecting data about apartment prices and other terms of concluded transactions.

The article presents the review of methods used to construct apartment price indices in order to select a method of determining a price index for a chosen local apartment market in the West Pomeranian Province.

The analysis covered 369 free-market sale transactions of cooperative apartments that had been concluded from 4 May 2000 to 18 August 2010 by a Housing Cooperative in the Zachód development in Stargard Szczeciński with the total number of 2,712 flats (constituting a stable and homogenous housing resource due to the time and technology of construction). To each transaction seven features have been attributed: a transaction date, a sale price, a property size, an address, a number of rooms, a floor and the number of floors in a building.

The author verified the hypothesis about the applicability of classic indices of price dynamics for a sample including transactions within a homogenous housing resource, even in the case of long series.

\section{Methodological Problems while Constructing Apartment Price Indices}

Dynamics indices are measures used to examine the size ratio of the same phenomenon in two different time periods. Depending on the base to which a given index relates there are fixed base and chain base indices. The base of the fixed index is a period characteristic of a given phenomenon $^{2}$, while the base of a chain index is a preceding period. Indices determined for a single time series are called individual. The ones determined for several series are known as aggregate indices. Due to diversity of apartments available on the market we should tend to divide the sample into groups that are homogenous because of their characteristics which, in the author's opinion, significantly affect market prices. It means that weighted aggregate indices 
should be determined. When a sample for which an aggregate index is calculated is very big, we can ignore the impact of individual groups of goods since weighted and unweighted indices will be identical or almost the identical. In addition, when calculating aggregate indices it should be assumed that side factors affecting prices are the same and the weights of individual goods do not change in the examined period. This assumption can be made for the apartment market when the perspective is short (a few years). For series longer than ten years we cannot assume that the apartment buyers' preferences are constant. Similarly, the influence of socio-economic environment on investors' decisions is not stable. It is an important element determining the behaviour of both the apartment buyers and sellers.

Price aggregate indices are most often weighted with the volume of goods, e.g. the Laspeyres index (when quantitative weights change significantly in subsequent periods), the Paasche index (a weight are quantities of the current period), the Lexis index (recommended when the change of price is more significant rather than the quantity of goods) or, finally, the Fisher index (a geometrical average of the Laspeyres and Paasche indices) ${ }^{3}$. The aforementioned price indices can be described as:

- Laspeyres index

$$
I_{L}=\frac{\sum p_{i} \cdot q_{o}}{\sum p_{o} \cdot q_{o}} \cdot 100
$$

- Paasche index

$$
I_{P}=\frac{\sum p_{i} \cdot q_{i}}{\sum p_{o} \cdot q_{i}} \cdot 100
$$

- Lexis index

$$
I_{L E}=\frac{\sum p_{i} \cdot q_{o}+\sum p_{i} \cdot q_{i}}{\sum p_{o} \cdot q_{o}+\sum p_{o} \cdot q_{i}}
$$

- Fisher index

$$
I_{F}=\sqrt{\frac{\sum p_{i} \cdot q_{o}}{\sum p_{o} \cdot q_{o}} \cdot \frac{\sum p_{i} \cdot q_{i}}{\sum p_{o} \cdot q_{i}}}
$$

where:

$p_{i}$ - price of article in time $i$,

$q_{i}$ - quantity of article in time $i$,

$p_{o}$ - price of article in basic period,

$q_{o}$ - quantity of article in basic period.

The apartment price indices determined for a given sample require a mean price for a given group instead of a merchandise price $p_{i}$ or $p_{o}$ in a relating period. 
In order to apply the above formulas in determining the apartment price indices it is necessary to meet the aforementioned assumptions for aggregate indices, which results in limiting the spatial scope of the analysis (housing markets are local and properties are not identical), and to assume that buyers' preferences are fixed in time. The former assumption allows to differentiate relatively homogenous groups of apartments due to their quantitative ${ }^{4}$ or qualitative traits and to construct the apartment price index for small areas, while the latter assumption can be met only in case of short time series ${ }^{5}$. The long-term disadvantage of applying these indices is the fact that the structural changes in housing resources on the market are not taken into account. Another index proposed for the real estate market in general, but which can be adopted specifically to the apartment market is an index based on a geometrical average of single-based apartment price indices (nominal prices) and of the number of transactions ${ }^{6}$ :

$$
I_{c_{t / t-1}}=\frac{c_{t}}{c_{t-1}} \quad \text { and } \quad I_{l_{t / t-1}}=\frac{l_{t}}{l_{t-1}}
$$

where:

$I_{c_{t / t-1}}-$ apartment price index in period $t$ relatively to period $t-1$,

$c_{t} \quad-$ price of $1 \mathrm{~m}^{2}$ of property in time $t$,

$c_{t-1}-$ price of $1 \mathrm{~m}^{2}$ of property in time $t-1$,

$I_{l_{t / t-1}}-$ number of transactions index in period $t$ relatively to period $t-1$,

$l_{t} \quad$ - number of transactions in time $t$,

$l_{t-1}-$ number of transactions in time $t-1$.

Price indices and transactions number indices are interpreted in relation to one. The number of transactions is linked to a unit price. The higher the prices, the less buyers are willing to buy, and vice versa. On the other hand, the price level depends directly on demand in the situation of temporarily limited supply. Therefore in order to objectify the index we should average both characteristics, thus obtaining a weighted price index $I_{t}$ (the price index weighted with the transactions number index). Because of a multiplicative character of index values, the following geometrical average formula was used:

$$
I_{t}=\sqrt{I_{c_{t / t-1}} \cdot I_{l_{t / t-1}}}
$$

The value of indices so constructed is related to one:

$I_{t}>1$ means the increase of prices in relation to previous year,

$I_{t}<1$ means the decrease of prices in relation to previous year,

$I_{t}=1$ means stable prices on the housing market in relation to previous year. 
In order to find a global apartment price index the aggregate indices for non-homogenous groups $^{7}$ (the $n$-th type of housing) can be used:

$$
I_{t / t-1}=\frac{\sum_{i=1}^{n} c_{i / t} \cdot l_{i / t}}{\sum_{i=1}^{n} c_{i / t-1} \cdot l_{i / t-1}}
$$

where:

$I_{t / t-1}$ - global absolute indices of business climate for the $n$-th type of housing,

$c_{i / t}-$ price of $1 \mathrm{~m}^{2}$ of property of the $i$-th type in year $t$,

$l_{i / t}-$ number of transactions of the $i$-th type in year $t$,

and $i=1,2, \ldots, n, t-$ subsequent years of the study.

The global price index maintaining above 1 over the period of several years means a boom on the real estate market; its staying below 1 means recession, while 1 means stagnation.

The solution to some of the above mentioned problems that the housing market researchers often face are, found in literature, hedonic regression models of apartment price indices ${ }^{8}$ as well as other models based on the apartment resale ${ }^{9}$. The hedonic index method is based on the regression model where the property price is a function of its characteristics (both quantitative and qualitative). Regression models estimated separately for each study period are used to determine the apartment price indices ${ }^{10}$.

In this method we assume the impact of the apartment characteristics on its price, to appraise which the following models ${ }^{11}$ are most frequently used:

- linear model

$$
\begin{gathered}
Y=\alpha_{o}+\sum_{i=1}^{n} \alpha_{i} \cdot X_{i}+U \\
\log Y=\alpha_{o}+\sum_{i=1}^{n} \alpha_{i} \cdot X_{i}+U \\
\log Y=\alpha_{o}+\sum_{i=1}^{n} \alpha_{i} \cdot \log X_{i}+U \\
Y^{(\lambda)}=\alpha_{o}+\sum_{i=1}^{n} \alpha_{i} \cdot \log X_{i}+U
\end{gathered}
$$

- semi-log-linear model

- log-linear model

- Box-Cox model

where:

$Y$ - endogenous variable,

$X$ - exogenous variable,

$U$ - error term. 
The linear model of hedonic regression to determine a property price index was described by Fleming and Nells ${ }^{12}$ who assumed that the dependency between a property (apartment) price and its value affecting characteristics can be expressed by a following equation:

$$
\ln \left(P_{i}\right)=b_{o}+b_{1} X_{1, i}+b_{2} X_{2, i}+\ldots+b_{j} X_{j, i}+e_{i}
$$

where:

$P_{i}-$ seller apartment price,

$X_{i}-$ seller apartment characteristics,

$b_{1}, b_{2}, \ldots, b_{j}-$ models coefficients,

$e_{i}-$ error term.

Qualitative characteristics in the model (12) adopt zero-one values. Estimating the model by means of the least squares method facilitates indicating the impact of variables $X_{j}$ on an apartment price $\mathrm{n}$ a given period. As the next step standardization should be performed by applying the system of weights to the characteristics in a chosen period.

\section{Cooperative Apartments Price Indices for the Housing Market in Stargard Szczeciński}

In order to determine the apartment price index the author used data about the local housing market in Stargard Szczeciński (a county capital ${ }^{13}$ ) where 369 cooperative apartments in the Zachód development belonging to the Housing Cooperative were sold on the free market in 2000-2010. This is a complete number of sale transactions in the Zachód development consisting of 2,712 apartments. What is more, the housing resources in that particular development are homogenous due to their technological parameters. The buildings were constructed in 1977-1978 by means of an industrialised technology (the Szczecin system WZ-70). There are five-storey (in this study described as low) and twelve-storey (high) apartment blocks. Each transaction provided information concerning:

$X 1$ data of transaction,

$X 2$ transaction price (PLN),

$X 3$ usable apartment area (sq. m),

$X 4$ number of rooms,

$X 5$ building level,

$X 6$ building height (low, high),

$X 7$ address. 
Since price indices are determined in relation to unit prices (PLN/sq. m of usable apartment area) this variable was analysed by means of defining its basic statistics (Table 1). Apart from 2007 there are no significant indications to replace an arithmetic average with a measure of location (a median) in further considerations. But, in order to unify proceedings the further calculations will be based on the unit price median.

Table 1. The unit prices indices basic statistics in the years of 2000-2010

\begin{tabular}{|c|c|c|c|r|r|r|}
\hline \multirow{2}{*}{ Years } & \multicolumn{7}{|c|}{ Selection descriptive statistics of 1 sq. m price (PLN) } \\
\cline { 2 - 7 } & Average & $\begin{array}{c}\text { Standard } \\
\text { deviation }\end{array}$ & Median & Kurtosis & Skewness & \multirow{2}{*}{ Range } \\
\hline 2000 & $1,317.58$ & 48.65 & $1,302.15$ & -0.62 & -0.13 & 581.68 \\
\hline 2001 & $1,355.24$ & 43.06 & $1,358.59$ & 1.65 & -0.38 & 902.04 \\
\hline 2002 & $1,326.11$ & 23.12 & $1,342.16$ & -0.26 & 0.26 & 624.61 \\
\hline 2003 & $1,336.44$ & 26.20 & $1,314.91$ & 1.56 & -0.01 & $1,126.83$ \\
\hline 2004 & $1,350.09$ & 41.41 & $1,321.88$ & -0.63 & -0.28 & 898.82 \\
\hline 2005 & $1,401.29$ & 27.47 & $1,416.70$ & -0.94 & -0.12 & 637.97 \\
\hline 2006 & $1,635.46$ & 46.66 & $1,642.86$ & 1.78 & 0.76 & $1,243.97$ \\
\hline 2007 & $2,639.95$ & 180.10 & $2,334.57$ & -1.68 & 0.30 & $2,095.24$ \\
\hline 2008 & $3,790.43$ & 63.24 & $3,761.90$ & 1.76 & -0.66 & $2,092.48$ \\
\hline 2009 & $3,549.45$ & 67.46 & $3,683.42$ & -0.76 & -0.30 & $1,799.76$ \\
\hline 2010 & $3,377.94$ & 76.83 & $3,483.18$ & 1.92 & -1.19 & $1,997.52$ \\
\hline
\end{tabular}

Source: own study on the basis of the data collected by the Housing Cooperative in Stargard Szczeciński.

One-based indices determined on the basis of the median and the average indicate two periods of price fall and one period of dynamic growth (Figure 1). By 2002 and since 2007 (the average) and 2008 (the median) the average apartment prices on the examined market have

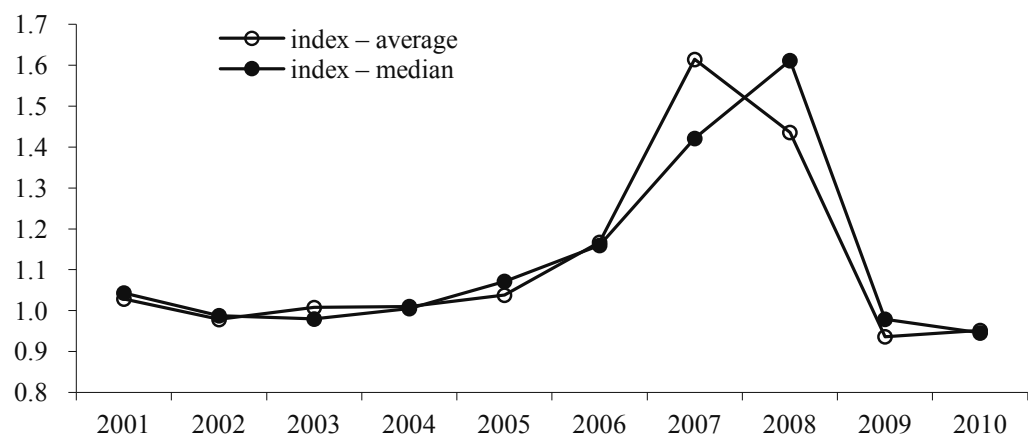

Fig. 1. The price index of cooperative apartments in the Zachód development in Stargard Szczeciński in the years of 2000-2010

Source: own study on the basis of the data collected by the Housing Cooperative in Stargard Szczeciński. 
been decreasing. In the two recent years the index value have been falling sharply, to the level below 1 . In 2008 the median of the apartment unit price fell by $8.5 \%$ in comparison to 2008 , while the median of the average price - by $11 \%$ when the mean inflation level was $3.5 \%$.

The analysis of apartment prices supplemented with the analysis of the index of the change in concluded transactions number ${ }^{14}$ shows that the best business climate was in 2008 when the highest prices did not discourage buyers from purchase (Figure 2).

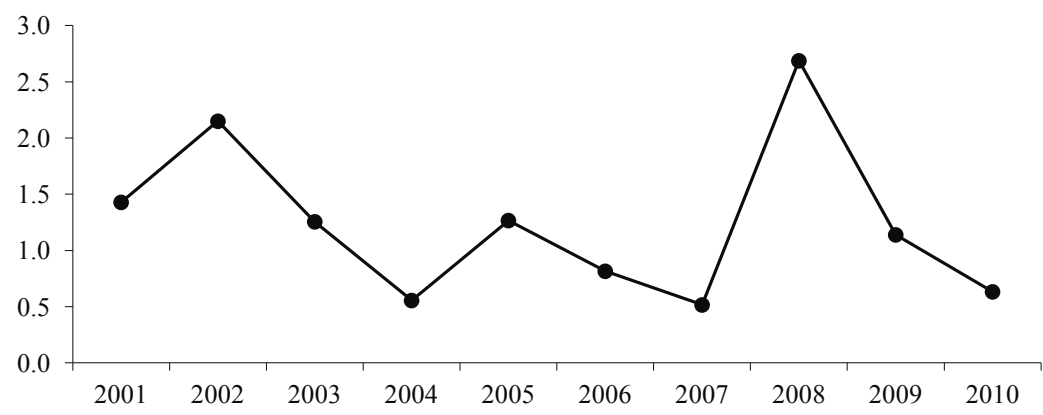

Fig. 2. The transactions number index of cooperative apartments in the Zachód development in Stargard Szczeciński in the years of 2000-2010

Source: own study on the basis of the data collected by the Housing Cooperative in Stargard Szczeciński.

Subsequently the author determined the price index geometric average based on the unit price median as well as the transactions number index (formula 6). The curve shape (Figure 3) implies a significant effect of the number of transactions on the index value. It also shows three full (four-year) phases of the price change in the studied time-span: 2001-2004, 2004-2007 and

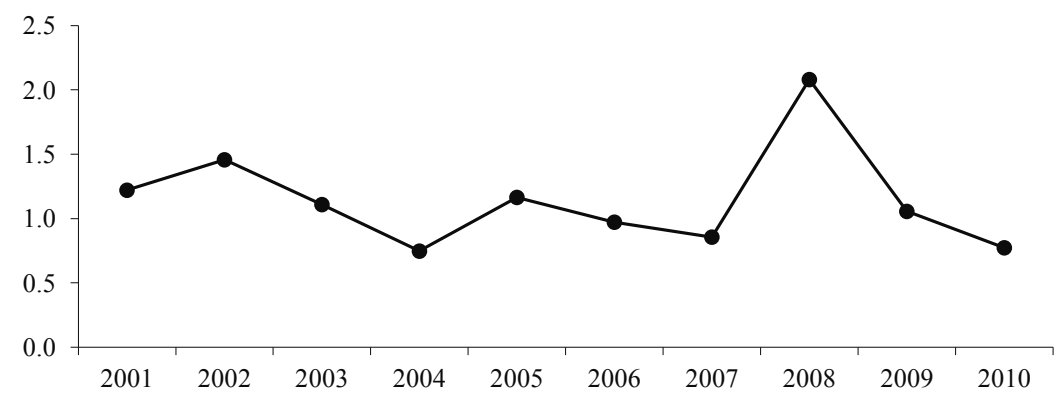

Fig. 3. Geometric price index of cooperative apartment transactions in the Zachód development in Stargard Szczeciński in the period of 2000-2010

Source: own study on the basis of the data collected by the Housing Cooperative in Stargard Szczeciński. 
2007-2010. The phases reflect the situation on the Polish apartment market: a slight recovery preceding Poland's accession to the European Union and a dynamic growth of the market by 2008 followed by a deep recession in the following years.

In order to compare the obtained results the author also determined the price indices (with a fixed base a for the Laspeyres index and with a chain base for the Paasche index) from the formulas 1-4. The results are presented in Table 2. Chain base indices are used for long time series, while the fixed base ones - for short time series. Each of the indices demonstrates different sensitivity to price changes. The Lexis index is considered the best of the ones presented above because researchers are interested most in the price change, not in the turnover volume. The Laspeyres and Paasche indices are sensitive to the turnover volume, particularly when they are defined in reference to the primary period where the number of transactions was small. Both of them, however, demonstrated the change in the apartment price growth dynamics in 2008 (or even as early as in 2007).

Table 2. Price indices of cooperative apartment transactions in the Zachód development in Stargard Szczeciński in the period of 2000-2010 (\%)

\begin{tabular}{|c|c|c|c|c|c|c|}
\hline$\%$ & Laspeyres $\left.{ }^{*}\right)$ & Laspeyres $\left.^{* *}\right)$ & Paasche*) & Paasche $\left.^{* *}\right)$ & Lexis ${ }^{*}$ & Fisher") \\
\hline 2001 & 1.08 & 103.85 & 69.70 & 69.70 & 2.09 & 8.68 \\
\hline 2002 & 1.01 & 64.56 & 48.33 & 45.66 & 2.49 & 6.99 \\
\hline 2003 & 1.06 & 32.90 & 79.60 & 81.44 & 4.10 & 9.17 \\
\hline 2004 & 1.07 & 26.00 & 182.63 & 179.00 & 5.06 & 13.96 \\
\hline 2005 & 1.12 & 48.40 & 81.43 & 79.29 & 3.34 & 9.55 \\
\hline 2006 & 1.30 & 42.58 & 131.63 & 121.45 & 4.27 & 13.10 \\
\hline 2007 & 1.90 & 65.63 & 239.47 & 193.75 & 4.73 & 21.31 \\
\hline 2008 & 3.05 & 137.32 & 68.83 & 37.47 & 5.11 & 14.50 \\
\hline 2009 & 2.83 & 30.45 & 252.26 & 87.87 & 11.70 & 26.73 \\
\hline 2010 & 2.75 & 27.10 & 439.36 & 161.39 & 12.61 & 34.77 \\
\hline
\end{tabular}

${ }^{*}$ fixed base indices, ${ }^{* *}$ chain base indices.

Source: own study on the basis of the data collected by the Housing Cooperative in Stargard Szczeciński.

Also, the author attempted to define the hedonic index with the use of a linear function (formula 12). The first step was to determine coefficients of the linear function for each of the studied years where explanatory variables are $X 4, X 5$ and $X 6$. The estimated models did not lead to satisfying results both because of the signs of the model coefficients and low values of $\mathrm{R}^{2}$ which did not exceed $50 \%$. Consequently, the author gave up further efforts to determine the hedonic index. 


\section{Conclusions}

The above considerations confirm the usefulness of classic indices of apartment price dynamics on a spatially limited market where it is possible to differentiate sets of apartments that are considered homogenous because of the similarity of their primary characteristics. Onebase indices indicate two periods of falling unit prices and one period of dynamic growth. The geometric price index implies significant influence of the transactions number on the index value and indicates three full four-year) phases of price change in the analysed period. The Laspeyres, Paasche, Lexis or Fisher indices confirm the change in the apartment prices dynamics in 2007-2008, but each of them demonstrates different sensitivity to price changes. The so determined indices supplement hedonic indices applied on the real estate markets, especially when information about a given transaction is not sufficient to estimate the price function, which is necessary in the process, or, as in this study, the obtained quality of the applied models is unsatisfactory.

\section{Notes}

1 Data concerning the quantity and quality of resources and new investments are collected and published by the Central Statistical Office of Poland, but they are not the primary data.

2 In Poland 1990 can be adopted as a base point. It was the year when legal regulations were adopted that opened a free real estate market. But high inflation of the early 1990s could distort the obtained price indices.

3 Aczel (2006), pp. 660-669.

4 Taking into consideration the qualitative features is usually quite difficult due to the lack of information in such source documents as notarial deeds.

5 Apartment buyers' preferences change with new technologies or fashion. More details see Foryś (2010).

6 See Foryś, Hozer, Olszanowski (2001) and Foryś (2002).

7 The criterion of division into homogenous groups can be any characteristic affecting the apartment price, such as: location, construction technology or size.

8 See Bailey, Muth, Nurse (1963), pp. 933-942 and Crone, Voith (1992), pp. 324-338.

9 Case, Shiller (1990).

${ }^{10}$ Introduction of time as a zero-one variable makes it possible to construct one regression equation instead several equations for each period.

11 These models presented in American publications are quoted by Trojanek (2008), pp. 47-48.

12 See Fleming, Nellis (1994), pp. 6-16 and Trojanek (2008), pp. 46-47.

${ }^{13}$ Due to its location (app. $40 \mathrm{~km}$ form Szczecin) the town is a social and economic back-up for Szczecin and the changes on the local housing market are delayed and less intense than in Szczecin.

14 The Pearson correlation index for these variables was 0.38 . 


\section{References}

Aczel, A.A. (2006). Statystyka w zarzadzaniu, Warszawa: PWN.

Bailey, M.J., Muth, R.F, Nurse, H.O. (1963). A Regression Method for Real Estate Price Index Construction. Journal of American Statistical Association, No. 58.

Case, K.E., Shiller, R.J. (1990). Forecasting Prices and Excess Returns in The Housng Market. National Bureau of Economic Research, Working Paper No. 3368, Cambrige.

Crone, T.M, Voith, R.P. (1992). Estimating House Price Appreciaction: A Comparision Metods. Journal of Housing Economics, No. 2(4).

Fleming, M.C., Nellis, J.G. (1994). The Measurement of UK House Prices: a review and Aprisal of the Proncipal Sources. Journal of Housing Finance, Vol. 24.

Foryś, I. (2002). Badanie koniunktury na rynku nieruchomości, Metody ilościowe w ekonomii, Prace Katedry Ekonometrii i Statystyki, ZN KEiS US 328, Szczecin.

Foryś, I. (2010). Wykorzystanie analizy korespondencji do badania preferencji nabywców mieszkań na zachodniopomorskim rynku nieruchomości mieszkaniowych. Taksonomia 17. Klasyfikacja i analiza danych - teoria i zastosowania. Prace Naukowe Akademii Ekonomicznej im. Oskara Langego we Wrocławiu nr 107, Wrocław.

Foryś, I., Hozer, J., Olszanowski, A. (2001). Koniunktura na rynku nieruchomości rolnych województwa szczecińskiego, Prace Katedry Ekonometrii i Statystyki ZN KEiS US, Szczecin.

Trojanek, R. (2008). Wahania cen na rynku mieszkaniowym, Poznań: Wydawnictwo Akademii Ekonomicznej w Poznaniu. 